\title{
Topical Issues of Interpretation of the Criminal Procedure Norms on the Basis of Judicial Practice Taking into Account the International and Russian Components
}

\author{
Tatyana Gennad'evna Borodinova \\ Anna Alexandrovna Petrikina \\ Vladimir Vladimirovich Borodinov \\ Irina Vladimirovna Gubko \\ The North Caucasus Branch of the \\ Federal State Budgetary Educational Institution of \\ Higher Education "Russian State University of Justice", \\ Krasnodar, Russia
}

Doi: 10.36941/ajis-2020-0041

\begin{abstract}
The research reveals the peculiarities of interpretation of the criminal procedure norms emphasizing the practical importance. Its purpose is to identify and solve problems of law enforcement in criminal proceedings. The nature and types of interpretation of the criminal procedure norms were subjected to $a$ detailed analysis based on the judicial and investigative practice. Difficulties with interpretation of the criminal procedure norms in connection with the legislative gaps, difficulties in the process of interpreting the cross-industry terms lack of digital information support of the newly published acts interpreting the norms of law and establishment of specific terms for its implementation, were singled out as separate problems. The use of a set of methods of scientific cognition was promotive of the achievement of the result. The conclusions show that the competent interpretation and application of the criminal procedure law by the courts, taking into account the specifics of this branch of law, can increase the efficiency of justice. The scientific novelty of this research is that for the first time, in an integrated manner and on the basis of a systematic analysis of the practice of interpretation and application of the norms of criminal law. It is planned to formulate proposals and recommendations to improve the work of the courts, law enforcement bodies and the advocacy suggesting specific measures to optimize the said direction.
\end{abstract}

Keywords: Court, prosecutor, defense counsel, interpretation, application, justice, fairness, judicial practice

\section{Introduction}

The idea of separation of state power in modern Russian society is aimed at serving for the benefit of man and citizen. Criminal justice is an area of public life where individual rights are most vulnerable (Bottoms, A., \& Tankebe, J. 2012). The court, as an independent arbitrator on behalf of the entire state, has the right to determine the further fate of an individual by determining his or her guilt or innocence of a crime. Having, in fact, unique powers, this public authority also bears the burden of 
enormous responsibility for the proper interpretation and application of the criminal procedure norms (Cumberbatch, J.R., \& Barnes, G.C. 2017). Judicial errors, related to misinterpretation and application of the criminal procedure law, threaten to distort the purpose of criminal proceedings and weaken the state in general as a social and political institution (Chivers, B., \& Barnes, G. 2018).

Scientific and educational literature often says that the majority of researchers criticize the legislative technique and quality of the criminal procedure law.

Indeed, there are separate reasons for this. The life situations are different. The most universal criminal procedure structure is not always able to meet the needs and requirements of society.

The procedure of interpretation always precedes the implementation of legal norms. Such necessity is conditioned by the establishment of the essence and action in the field of legal norms. It is important to determine the place of criminal procedure norms in the general system of legal regulation. The life and fate of many people, the correct and socially just implementation of the state criminal policy is dependent on the correct, accurate and uniform understanding of criminal procedure norms and their correct application.

Interpretation of the criminal procedure law is a complex process of perception of verbal information. The legal verbal form should not distort the meaning of legal terms.

The criminal process serves as a framework for the protection of human rights and freedoms, law and order, so a clear explanation of the meaning of criminal procedure norms is essential, as well as their uniform application by all participants in criminal proceedings.

It should be noted that it is not only the application of criminal law and criminal procedure law that needs a clear and precise understanding of the content of the existing legal norms. There is a need for this in other forms of law enforcement (compliance, enforcement, use).

Special attention should be paid to the interpretation that is carried out in the course of legislative activity. Development of new criminal procedure norms and their systematization is impossible without knowledge of the general legal principles of the legislation system architecture.

Constitutional interpretation is important for the legislative process, as the principles and norms enshrined in the Basic Law serve as the basis for all current criminal procedure legislation. Interpretation of legal norms also takes place in the process of elimination of legal illiteracy and legal nihilism. The interpretation is essential for all aspects of criminal proceedings.

\section{Methods and Data}

In order to carry out this scientific research, it is supposed to apply a set of methods: the method of dialectical cognition, general scientific methods (system analysis and synthesis, generalization, induction, deduction, analogy), as well as private scientific methods (historical, comparative legal, statistical, particular sociological, etc.).

The research will be carried out on the basis of the law enforcement practice of the European Court of human rights, as well as the various components of the judicial system of the Russian Federation that carry out judicial proceedings in criminal cases, and of preliminary investigation bodies and defense counsels.

The need for interpretation of criminal procedure norms arises because of their abstractness, their meaning does not always seem to be clearly defined and applied to the criminal procedure relations existing in reality, possessing properties of individual certainty and uniqueness.

It has to be clarified in each specific situation whether there are criminal procedure norms covering it. Whether they can be properly implemented or whether there is a legislative conflict or gap.

The judgment of the European Court of Human Rights on complaint \# 13810/o4 "Shamardakov against Russia" (issued on April 30, 2015, entered into force on July 30, 2015) indicates a violation of the right to a fair trial courts.

The applicant claimed that the domestic courts obtained evidence by way of his ill-treatment in the absence of a lawyer during his detention by law enforcement bodies. 
The European Court concluded that “...regardless of the impact that the applicant's initial testimony, given as a result of inhuman and degrading treatment, could have had on the outcome of the proceedings against him, its preservation in the case file deprived the proceedings as a whole of fairness... Thus, there has been a violation of Article 6(1) of the Convention".

With regard to the use of evidence obtained in the absence of a lawyer, it was stated that "... In accordance with generally accepted international standards, the accused should (as soon as he or she is deprived of liberty) be able to benefit from the assistance of a lawyer, regardless of whether or not he or she is being questioned... A fair trial requires that the accused be able to receive the full range of measures that relate to counseling. In this regard, the discussion of the case, the organization of the defense, the search for evidence in favor of the accused, the preparation for questioning, the support of the accused in this situation and the monitoring of the detention conditions are the main elements of the defense to be addressed by a lawyer" (The judgment of the European Court of human rights on the complaint of \# 13810/04 "Shamardakov against Russia").

The Russian Criminal Procedure Law does not contain a clear list of legal remedies in any of its articles. That's why in this case, its interpretation is not entirely correct and has led to what the European Court of Justice considers to be an unjust judgment.

A legislative gap is evident. It could be successfully filled by adoption:

- $\quad$ at the international level, of the Convention on the Legal Protection of Individuals;

- at the national level, of the Code of Legal Protection of Individuals and Citizens in the Russian Federation.

Such regulatory legal acts should clearly specify the subjects of legal assistance, the forms of legal assistance in the various types of proceedings, the manner and means of its provision.

In support of the need for the above recommendation we can also cite an excerpt from the defensive speech in one of the criminal cases heard by the Krasnodar regional court.

"... From the testimony of a witness given during the trial, it follows that the accused met with someone on September 28, 2012, and was excited after the meeting. Later, deceiving him and his brother, in the afternoon of September 28, 2012, he left the house alone. He learnt that the accused was supposed to have a meeting with other members of the organized group in the cemetery area. To prevent conflict, the witness decided to go after the accused and take him back. To do so, he stopped a friend of his who was driving his own car and who agreed to give him a ride to the specified place. Upon arrival, he was able to persuade the accused to return to the city. And there were no other persons in the cemetery except the accused. On his way to the city, the accused, riding in front of his car, turned around and drove back to the cemetery, pointing at his phone and making a gesture that someone was calling. Further events are interpreted differently by witnesses.

One of them changed his testimony in the course of the investigation, but in court he explained the reason for his conduct and reported that only during the trial he gave fully truthful testimony, as he did not trust the pre-trial investigation body. His explanations seem quite logical and consequential. The defense was given the opportunity to pose any questions to the witness and to incriminate him, but all of the witness's answers were clear and logical, thus indicating their veracity". (Fragment of the defense speech in the criminal case \# 2-31 / 2015, considered by the Krasnodar regional court).

Interpretation of law is a system of knowledge, which is called legal hermeneutics. It analyzes and generalizes the principles of interpretation of legal norms, methods and techniques of interpretation of legal texts, including those containing norms of criminal and procedural law. Interpretation here is a complex mechanism allowing, through a set of applied logical techniques, to obtain information reflecting the meaning (content) of the legal norms. The result of this thinking activity provides an opportunity to deeper study the situation in society, mediated by the legal norms. Interpretation has a dual nature, allowing, on the one hand, to carry out the epistemology of legal norms, and, on the other hand, to achieve the result in the form of understanding the content of legal norms and their meaning.

The independent interpretation of criminal procedure norms has the meaning in the course of 
scientific or everyday cognition of legal phenomena of public life and is largely conditioned by certain types.

Systematic interpretation is a necessary condition for the proper qualification of a crime by the pre-trial investigation bodies and the court. Without a systematic way of interpretation, it is impossible to understand the content of the majority of norms of criminal and criminal procedure laws of Russia. For example, the issue of ensuring the information security of minors is very acute in the world.

In its turn, Russia has developed a whole system of measures at the legislative level, which has established additional mechanisms to counteract activities aimed at encouraging children to commit suicide. Article 42 of the Code of Criminal Procedure mentions "harm" and "business reputation", and Article 110 of the Criminal Code, "forcible suicide", was supplemented by a number of qualifying elements, including the commission of the crime against a minor, a pregnant woman, two or more persons, a group of persons by prior agreement or an organized group, as well as in public appearances, the media or information and communication networks. However, without systematic interpretation, the application of this norm would be significantly hindered, since neither criminal nor criminal procedure laws of Russia contain the concept of "harm", "business reputation", "pregnancy", "mass media", "information and communication networks", etc. In order to properly qualify and adequately promote a criminal case, it is necessary to refer to other laws and regulations.

The solution of a whole range of criminological, criminal and organizational problems aimed at the effective functioning and further improvement of the system for the prevention of juvenile delinquency depends directly on a proper understanding of the norms of the criminal and criminal procedure codes of the Russian Federation.

However, it is not possible to implement systematic interpretation in criminal proceedings to the full extent. Due to the existence of restrictions prescribed directly in the very criminal procedure law of Russia (Article 1). But this type of interpretation, on the one hand, contributes to the identification of legal conflicts, and on the other hand, to the application of the analogy of the law, if necessary. This means that systematic interpretation involves the identification of all other legal norms that may, in one way or another, affect the understanding of the content of a particular legal norm. When we try to apply the analogy of the law to the criminal procedure relations, we should remember, first of all, their specific features, which do not allow us to do it in full.

Firstly, we cannot say that the Russian legal system currently possesses full internal coherence, consistency in consolidating its basic principles, and is fully logical.

Secondly, often when referring to the terms of other branches of law, for example, civil, family, penal enforcement, etc., and trying to apply them to the interpretation of the criminal procedure norms, their initial meaning is distorted through the prism of criminal proceedings, adapting to its needs.

It is also important to note the importance of the legal method of interpretation of the criminal procedure norms, which is a special way of understanding the meaning of the content. It is based on professional knowledge of legal science and legislative techniques. Legal analysis involves the use of legal tools, i.e. scientific knowledge allowing studying the content of the legal structure of the norm and technical and legal means.

It is possible to disclose the exact meaning and content of criminal procedure norms and thus ensure the correct application of the criminal procedure law in an overwhelming number of situations only with the help of special legal knowledge. That is why legal interpretation is central to other ways of interpretation in criminal proceedings.

Citizens, lawyers, specially authorized law enforcement bodies, officials, courts, scientific institutions and scientists are subjects of interpretation of criminal procedure norms. The consequences of such activities will vary. Anyone can turn to the norms of the Code of Criminal Procedure if they wish, find the article they are interested in and thoroughly study it, comprehend it, understand the content of the guideline or ban, and to draw necessary conclusions for themselves. However, these actions will have no significance for the participants in the criminal proceedings and 
will not cause any legal consequences.

Official interpretation is mandatory. It is given by the competent authorities and officials authorized to do so. It is documented in special acts (acts of interpretation); it causes certain consequences and leads to an unambiguous understanding of the norm to be interpreted and to its correct application. In its turn, a number of subtypes are distinguished among official interpretations:

- normative (general) and ordinary (individual);

- authentic (author's);

- legal (allowed, delegated);

- judicial.

Normative interpretation: This is usually a judicial interpretation in the form of decisions of the Plenum of the Supreme Court recommending that all subordinate courts adhere to certain requirements and milestones in the application of a particular law, consideration of a particular category of cases. This is one of the most complex and important areas of judicial activity, sometimes requiring high moral and ethical qualities from its subjects and high qualifications supported by regular practical activities in the judicial system. One of the current problems in this area is the lack of digital information support for newly issued acts of legal norms interpretation. As a solution to this problem, it is possible to propose the creation of a special digital information platform for courts of general jurisdiction, in which all enforcers who would be registered and identified could ask questions directly and without intermediaries to the Secretary of the Plenum of the Supreme Court of the Russian Federation, arising in the first 2-3 years in connection with the use of these acts in practice, and quickly get an answer to them.

Casual interpretation (from the word "casus", a specific case) refers to a certain fact, case, misdemeanor (Weisburd, D. 2015). This interpretation is valid only for a certain unique case.

For example, extending the period of detention of an accused person can only take place if there is sufficient evidence to show that there are grounds for the continued application of this preventive measure, as provided for by criminal procedure law (Barnum, J.D., Caplan, J.M., Kennedy, L.W., \& Piza, E.L. 2017).

Whereby, the circumstances under which a person was taken into custody are not always sufficient to extend the period of his or her detention.

The resolution of Slavgorod town court of Altai Territory dated December 25, 2017 extended the period of detention up to 5 months, i.e. up to February 28, 2018, for the accused of robbery and extortion by pre-trial investigation bodies.

The decision appealed was not reviewed. The resolution of the Presidium of the Altai Territory Court dated July 31, 2018 left this resolution unchanged.

In the cassation appeal the lawyer in the interests of the accused indicated that the court of first instance formally considered the application of the investigator for the extension of the measure of restraint in the form of detention to the accused, deviated from the study of the validity of the arguments presented in the petition and without proper verification extended the period of detention.

The Judicial Collegium for Criminal Cases of the Supreme Court of the Russian Federation annulled the resolution dated December 25, 2017 and the resolution of the Presidium dated July 31, 2018 on the following grounds.

A preventive measure shall be cancelled when it is no longer necessary, or it shall be changed to a more severe or softer measure, when the grounds for choosing a preventive measure are changed.

Contrary to the provisions of current legislation, when deciding to extend the period of detention of the accused, the court limited itself to enumerating the grounds set out in the relevant petition, which had already been taken into account by the court both at the time of choosing the measure of restraint in the form of detention and at the time of the subsequent extension of the detention period up to 3 months, without finding out whether the accused was still likely to have committed the acts enumerated in the criminal procedure law of the Russian Federation, and whether it was confirmed by the submitted materials, and failed to indicate the specific reasons justifying the necessity of prolongation of the accused's detention (Definition of Judicial Board on 
criminal cases of the Supreme Court of the Russian Federation of 27.02.2019 \# 51-UD18-16).

Authentic (author's) interpretation is an interpretation coming from the body or official who issued the interpreted normative legal act. It is an interpretation by the state authorities of their own acts.

The interpretation of the law of criminal procedure by the Constitutional Court of the Russian Federation is of particular importance among judicial interpretations, as it has the exclusive prerogative to interpret the Constitution of the Russian Federation and other fundamental acts.

Thus, in the Resolution of the Constitutional Court of the Russian Federation dated March 22, 2018 \# 12 "In the case of verification of the constitutionality of Article 107(1) and (3) of the Russian Criminal Procedure Code in connection with the complaint of Mr. S.A. Kostromin", the Constitutional Court indicated when the suspect or accused of a crime of little gravity can be placed under house arrest.

With regard to these persons, this measure may be chosen only if imprisonment may be imposed as the most severe form of punishment for this crime. This is also possible if there are exceptional cases provided for by the criminal procedure code of the Russian Federation for choosing a preventive measure in the form of detention, in which house arrest can be applied:

- the suspect does not have a permanent place of residence in Russia;

- his identity has not been established;

- he violated the previously chosen preventive measure;

- $\quad$ he fled from the pre-trial investigation bodies or from the court.

The Russian Constitutional Court, taking into account the above, concluded that the verified norms correspond to the Constitution of the Russian Federation.

It is essential not to confuse acts of interpretation of the law with sources of law. The court precedent in Russia is not officially recognized as a source of law. Many researchers and practitioners of criminal procedure law in Russia have long been for legitimizing it.

It is also essential that the Constitutional Court cannot interpret the Constitution and other normative acts containing criminal procedure norms on its own initiative. It is possible to do so only on the written initiative (request) of the respective subjects specified in Article 125 of the Russian Constitution (the President of the Russian Federation, the State Duma, the Council of Federation, the Government, the legislative authorities of the constituent units of the Russian Federation), as well as on the basis of complaints from citizens. The Constitutional Court makes a decision on the conformity of laws, other legal acts and individual norms of the Constitution issued in Russia. If they or their separate parts are acknowledged as unconstitutional, they become null and void. For criminal proceedings, the procedure of such kind of authentic interpretation is connected with the problem of observance of a reasonable term as the Russian criminal procedural law (articles 238 and 413) prescribes either to suspend the criminal case or, if the sentence has already been passed, to review it in connection with the newly discovered circumstances. Unfair participants, both for the defense and for the prosecution, may thus deliberately delay the duration of the criminal case (McLeod, M. 1983). This may be motivated by the termination of the criminal case due to the expiration of the limitation period, anticipation of amnesty, amendments to the current criminal and criminal procedure legislation and their entry into force, which significantly improves the situation of one of the parties. In order to avoid this, it is necessary to clearly establish a minimum and maximum period of time for the authentic interpretation of laws.

Of course, the official interpretation of the law may also be given by the executive authorities (Johnson, S.D., Tilley, N., \& Bowers, K.J. 2015) implementing criminal policy (the Government, its subordinate ministries, departments, services, committees), but within the scope of their competence. Most often these structures give an authentic interpretation, i.e. explain their own acts (resolutions, orders, instructions), especially on criminal procedure or organizational issues (Manning, M., Wong, G. T. W., Graham, T., Ranbaduge, T., Christen, P., Taylor, K. 2018).

Unofficial interpretation comes from subjects whose activity is not official or public, and therefore it has no legal force and no legal consequences. 
Let's consider the types of such interpretation in a schematic form (figure 1).

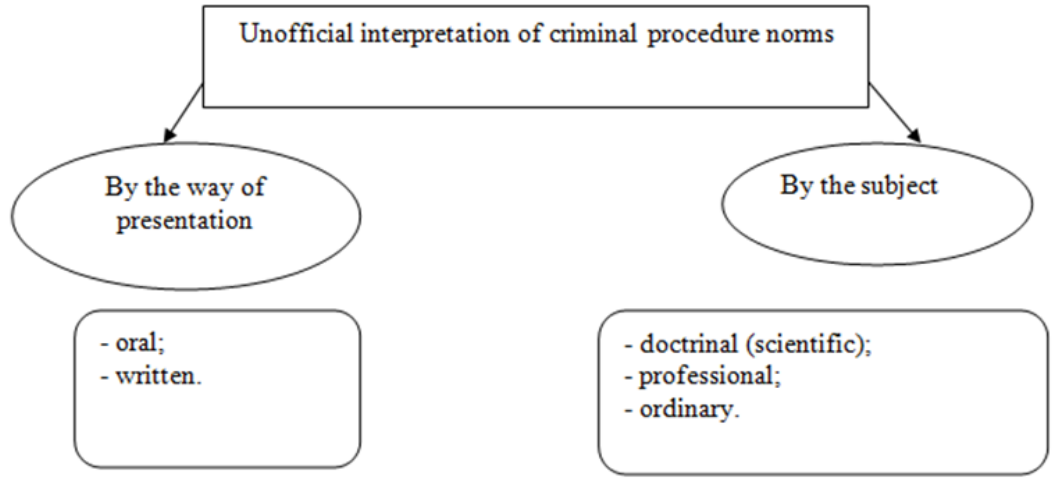

Figure 1: Types of unofficial interpretation

A characteristic feature of the unofficial interpretation of the criminal procedure norms is that it is not related to the method of coercion, which is provided by the state authorities.

Doctrinal interpretation is given by scientists, representatives of the criminal procedure studies. Its value lies in the fact that with the help of professional categories and terms the essence of criminal procedure norms is revealed logically, consistently, systematically and argumentatively. Examples of such interpretation are periodical scientific publications, individual publications and comments on specific criminal procedure norms or their system. Within the scientific articles, reports and monographs, specialists explain and interpret the relevant provisions, norms and articles of criminal procedure law. Thus, the views of scholars, while not binding, but worthy of attention for officials and bodies (judges, prosecutors, investigators, interviewers), as well as lawyers and reflecting current views and recommendations, can indeed provide substantial assistance to law enforcement practice and affect it.

Professional interpretation, as it can be seen from its name, is given by specialists in the field of law, in general by persons with higher legal education, who are well aware of the current criminal procedure law and practice of its application (figure 2 ).

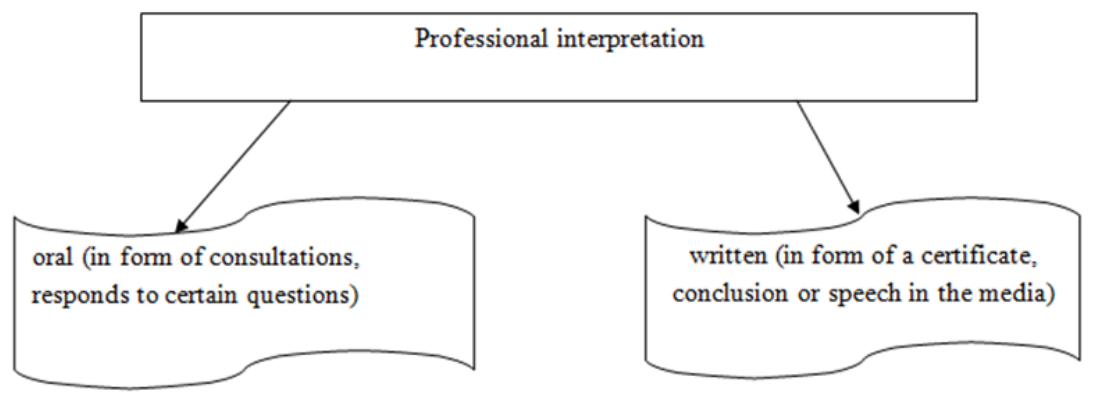

Figure 2: Types of professional interpretation

Ordinary interpretation is the primary, everyday level of understanding of the criminal procedure legislation, its interpretation by the citizens of the state. This type reflects legal consciousness of the population of the Russian Federation. Its peculiarity is that sometimes it has a distorted, incorrect character. The elimination of legal illiteracy and legal nihilism is of great importance in the 
performance of legally significant actions by citizens, the exercise of their rights and obligations, and observance of the law, law order and criminal procedure norms.

In 2017-2018, the reform of jury trials in criminal proceedings was carried out in Russia. This composition of the court now takes place at the level of district/city and constituent unit of the Russian Federation.

They are representatives of the people, do not belong to professional participants in court proceedings, and do not act on behalf of the state or local authorities. However, it should be noted that their verdict is binding on the court. This provision of the Russian criminal procedure law (Art. 348 ) is followed by the conclusion that the interpretation of the law, which they give in criminal proceedings, cannot be considered absolutely unofficial. Nor can it be considered official, since the final decision on the criminal case is taken by the presiding judge. It seems logical to single out an independent group, i.e. a special interpretation and to attribute the studied issues to it.

The procedure of interpretation of the criminal procedure norm passes through understanding and explanation of its meaning. The understanding personifies the gnoseological nature of the interpretation oriented to cognition of a criminal procedure norm. It acts as a thought process occurring in the mind of the subject, who interprets it.

Understanding and explanation are two interrelated aspects of a single legal norm's interpretation process. The interpreter, before explaining the content of the legal norm to others, must understand its meaning himself. This is necessary to ensure that the content of the criminal procedure law is clear to other participants in criminal proceedings (Figure 3).

Figure 3: Understanding and explanation of criminal procedure norms

\begin{tabular}{|c|c|}
\hline Internal orientation & External orientation \\
\hline $\begin{array}{l}\text { Understanding arises and exists when participants in criminal } \\
\text { proceedings disclose the content of the criminal procedure norms } \\
\text { "for themselves" in order to implement them, in other words, } \\
\text { establish their rights and obligations contained in the legal norm of } \\
\text { the criminal procedure law. }\end{array}$ & $\begin{array}{l}\text { Explanation is valid in cases where the } \\
\text { enforcer brings to all subjects of law the } \\
\text { true content of the text of the criminal } \\
\text { procedure law (norm) which the legislator } \\
\text { tried to express. }\end{array}$ \\
\hline
\end{tabular}

Before applying a rule of criminal procedure law, the enforcer must have a clear understanding of the content of the legal terms laid down by the legislator (Curtis-Ham, S., \& Walton, D. 2017), as well as the linguistic and logical structure of the specific criminal procedure norm. In addition, it is necessary to establish its place in the system of sources of criminal procedure law and, in some cases, the reasons and prerequisites for its issuance.

The above specificity of analyzing the criminal procedure law is conditioned by the fact that the terms, formulations and word combinations used in its prescriptions are not always absolutely clear, evident and unambiguous (Johnson, S.D., Tilley, N., \& Bowers, K.J. 2015), as well as by the fact that the enforcer has to mentally apply a more or less abstract construction to the circumstances of a particular case, which may be individual and unique.

The understanding of the meaning of the criminal procedure norm occurs by comparing it with other norms of criminal procedure law, revealing its legal force, scope of action, belonging to a certain institution of criminal procedure law.

An explanation occurs when it is by a subject who is not a party to the criminal procedure relations in question, within which the rights and obligations of the parties are explained, in order to explain and set forth the will of the legislator, as expressed in the sources of criminal procedure law.

One should refer 1) grammatical; 2) logical; 3) historical; 4) systematic; 5) comparative; 6) teleological (depending on the purposes of normative acts issuance) to modern methods of interpretation of criminal procedure norms.

Let's analyze frequently occurring problems of grammatical interpretation of the criminal procedure law in practice. 
According to the official statistics for the period from 2011 to 2016, more than 24 billion rubles have been reimbursed to the state in criminal cases of corruption crimes, and, in addition, the property of the accused persons has been arrested for the amount of more than 40 billion rubles.

It is worth noting that although the Russian Criminal Procedure Code contains the terms "legal entity", "damage" and a number of others, it does not give their interpretation in its norms. And when they are interpreted grammatically, any enforcer inevitably uses the rules of other branches of law and the rules of the Russian language. For the sake of justice, it should be noted that the meaning of these words and some grammatical constructions have long ago acquired a universal character and common understanding in the Russian legal system, and have become such for several, rather than one science.

It is not surprising, therefore, that various government agencies, including the Investigative Committee, the Prosecutor's Office, the police, the Chamber of Accounts, the Bank of Russia, Russian Federal Service for Financial Monitoring and the Federal Tax Service, are involved in improving procedures on compensation for damage caused by corruption, for example. Since 2011 to date, according to the criminal cases filed to the court, the number of accused persons who have committed crimes of corruption and who have been subjected to special criminal proceedings has been almost 4 thousand (3958). This suggests, first of all, that there are fewer difficulties with grammatical interpretation in criminal proceedings now (Interview of the Chairman of the Investigative Committee of the Russian Federation A. Bastrykin "Rossiyskaya Gazeta" 25.07.2017).

However, it's not all so smooth. The Chairman of the Investigative Committee of Russia has repeatedly stated that it is necessary to introduce the institute of criminal liability for legal entities into the Russian legislation (instead, administrative liability of organizations was envisaged in our country). He motivates it by the fact that in the overwhelming majority of cases the money and financial instruments acquired through corruption are transferred abroad through legal entities.

Indeed, in all European countries of English-American law and many other states, including in the post-Soviet space, a legal entity is considered a separate subject of crime. However, only through the grammatical interpretation of this term in jurisprudence, one can get a clear understanding of one's lack of consciousness and will which are necessary components of guilt. And the very complex of property relations, although having a special legal status by virtue of certain characteristics cannot commit a crime. However, the damage caused by the crime to legal entities can be undoubtedly inflicted, that is why they are recognized as victims by the Russian legislation.

Another problem related to the grammatical interpretation of certain norms of the Criminal Procedure Law is the lack of a universal understanding by the international community of individual procedures for bringing persons to criminal responsibility in the provision of international legal assistance in criminal cases. The court, prosecutor, investigator, interviewer face these difficulties when the deed should be criminally punishable both in the country initiating the international request and in the country executing such request, including on the grounds of the subject of crime. Extraterritorial criminal prosecution by the Russian law enforcement of executives and founders of companies registered in foreign jurisdictions also suffers from this, and, accordingly, it leads to impossibility to enforce their property.

In order to resolve this difficult situation, it is necessary to come to the international unification of criminal and criminal procedure terms.

As a rule, only grammatical interpretation in criminal proceedings is not enough, and other methods should be used. Perhaps, the most difficult thing is a systematic interpretation. Here, one should have excellent knowledge of the criminal procedure law, be confident in it, follow the development of science in this field and be able to understand the judicial practice. In difficult situations, the essence of an institution of the criminal procedure law can be understood only through the prism of historical development or in a comparative legal context. 


\section{Research results}

The data presented in combination with the methods used in the complex allow us to sum up some of the results:

1. The problem of interpretation of criminal procedure norms related to the existence of gaps and conflicts, both at the international and national levels can be resolved by unifying individual institutions in the field and enshrining them in international and national laws and regulations.

2. Difficulties of using cross-industry terms in the process of interpretation are conditioned, to a great extent, by the ambiguity of their meaning, if we do not take into account the specifics of criminal proceedings.

3. Difficulties arising from the use of normative interpretation are mainly related to the lack of information support. They can be resolved by creating a special digital forensic platform with the possibility of prompt feedback.

4. The disadvantage of authentic interpretation in criminal proceedings is the frequent violation of reasonable timelines for consideration of a criminal case. It can be solved by setting minimum and maximum timelines for its implementation.

5. The impossibility of attributing the interpretation of the criminal law and criminal procedure law by jurors to either the official or unofficial group has led to a proposal for another type of interpretation that is a special interpretation of the rules of law.

\section{Conclusion}

According to the statistics of the Russian State Duma Committee, Russia ratified 66 out of 225 treaties of the Council of Europe, including the Convention for the Protection of Human Rights and Fundamental Freedoms (in 1998), the European Convention for the Prevention of Torture and Inhuman or Degrading Treatment or Punishment (in 1998), the European Social Charter (in 2009), and the Convention on the Counterfeiting of Medical Products and Similar Crimes involving Threats to Public Health (in 2018). Another 16 conventions and protocols have been signed and are awaiting ratification. In particular, the Russian Federation was among the first countries to sign the Protocol amending the Convention for the Protection of Individuals with regard to Automatic Processing of Personal Data on October 10, 2018, and the Convention on Combating Crimes against Cultural Property on November 8, 2018. Based on the requests of the Russian authorities, the directions of cooperation are planned for 2017-2020. On November 21, 2018, in Strasbourg, the EU-Russia consultations on the programs for 2019-2020 were held, and an updated program document was presented, which was finally agreed between the parties in April 2019. Among the priorities in the work of the Russian experts is the professional development of representatives of legal professions in the Russian Federation (Russia in the Council of Europe. Reference material of the Russian State Duma Committee on International Affairs 2019). It can be said that the first steps to unify individual criminal justice institutions and enshrine them in international and national laws and regulations have already been taken, but they are insufficient. They lack a systematic and sectoral presentation.

The problem of interpreting cross-industry terms in criminal proceedings is clearly illustrated by the statistical indicators in tables 1 and 2, as well as figures 1 and 2. (Statistics of the Russian Supreme Court Justice Department for the $1^{\text {st }}$ half of 2019). 


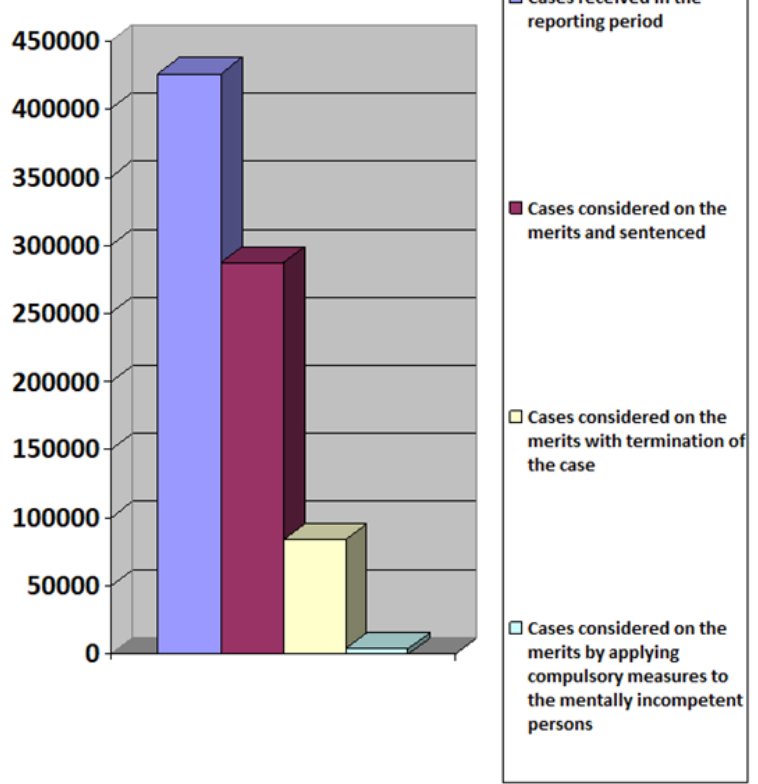

\section{Schedule 1.}

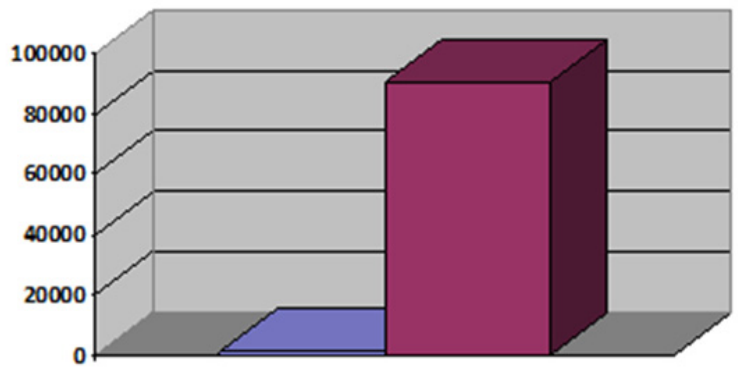

$\square$ On rehabilitative grounds: no event, no body of a crime

$\square$ Under o ther grounds

\section{Schedule 2.}

Table 1. Structure of cases received in the 1st half of 2019 by the Russian courts of general jurisdiction.

\begin{tabular}{|l|c|}
\hline Cases received in the reporting period & 425806 \\
\hline Cases considered on the merits and sentenced & 287427 \\
\hline Cases considered on the merits with termination of the case & 83765 \\
\hline $\begin{array}{l}\text { Cases considered on the merits by applying compulsory measures to the } \\
\text { mentally incompetent persons }\end{array}$ & 3906 \\
\hline
\end{tabular}

Table 2. Termination of criminal cases in court in the $1^{\text {st }}$ half of 2019.

\begin{tabular}{|l|c|}
\hline On rehabilitative grounds: no event, no body of a crime & 808 \\
\hline Under other grounds & 90592 \\
\hline
\end{tabular}


It is worth noting that the Russian judicial system is generally good at dealing with the problem of ambiguity in the interpretation of cross-industry terms, but the prevalence in the total number of terminated cases by the grounds other than "no event" and "no body of the crime" indicates that the difficulties still remain. This conclusion is also confirmed by the small number of criminal cases that have resulted in an acquittal - 1078 .

Information support for normative interpretation should be provided through active interaction between representatives of the judicial branch and technical developers of special software. In this case, it is necessary to go beyond individual consultations and to make the process continuous and systematized.

The conventional principle of reasonable period of time in the Russian criminal procedure has emerged relatively recently. However, modern sources of criminal procedure law still contain certain gaps that allow the parties to abuse their rights. The solution was largely facilitated by the improvement of legislative techniques in this regard.

Jury members are available in many countries around the world, especially among those belonging to the Anglo-Saxon legal family. The main law of the Russian Federation speaks of the mandatory inclusion of people's representatives in the consideration of criminal cases. The last conclusion is more related to the development of theoretical bases of interpretation of criminal procedure norms and is subject to further discussion by the scientific community.

\section{Reference}

Curtis-Ham, S., \& Walton, D. (2017). The New Zealand index of a damage from crimes: quantitative damage assessment using data on sentencing. Policing: a journal of policy and practice. https://doi.org/10.1093/police/paxo50

Chivers, B., \& Barnes, G. (2018). Sorry, wrong number: the tracking of attendance of the court targeting through testing and" push "the text. Cambridge journal of evidence-based police, 2, 4. https://doi.org/10.1007/s41887018-0023

Cumberbatch, J. R., \& Barnes, G. C. (2017). That push wasn't enough: a randomized study of text messages with reminders of court dates for victims and witnesses. Cambridge Journal of provided Based Policing, 2, 35. https://doi.org/10.1007/s41887-018-0024-4

Johnson, S. D., Tilley, N., \& Bowers, K. J. (2015). Familiarity with EMMIE: evidence assessment scale to encourage synthesis reviews of mixed crime prevention techniques. Journal of experimental criminology, 11 (3), 459473 .

McLeod, M. (1983). The victim's refusal to cooperate in the prosecution of domestic violence. Criminology, 21, 395416.

Johnson, S. D., Tilley, N., \& Bowers, K. J. (2015). Familiarity with EMMIE: evidence assessment scale to encourage synthesis reviews of mixed crime prevention techniques. Journal of experimental criminology, 11 (3), 459473 .

Manning, M., Wong, G. T. W., Graham, T., Ranbaduge, T., Christen, P., Taylor, K. (2018). Towards a" smart " costbenefit tool: using machine learning to predict the costs of criminal justice policy interventions. Criminal Science, 7, 12. https://doi.org/10.1186/s40163-018-0o86-4

Barnum, J. D., Caplan, J. M., Kennedy, L. W., \& Piza, E. L. (2017). Crime kaleidoscope: an interagency analysis of place and crime characteristics in three urban environments. Applied Geography, 79, $203-211$. https://doi.org/10.1016/j.apgeog.2016.12.011

Weisburd, D. (2015). The law of concentration of crime and criminology of place. Criminology, 53 (2), $133-157$.

Bottoms, A., \& Tankebe, J. (2012). Beyond procedural justice: a dialogical approach to legitimacy in criminal justice. Criminal Law and Criminology, 102, 119-169.

The judgment of the European Court of human rights on the complaint of \# 13810/04 "Shardakov against Russia". Date of issue 27.10.2019. http://www.consultant.ru/document/cons_doc_LAW_196727 /eза9c25703d2712a711eeo7102fbc7cbcd4dc9e7/.

Fragment of the defense speech in the criminal case No. 2-31 / 2015, considered by the Krasnodar regional court.

Russia in the Council of Europe. Reference source of the State Duma Committee on Foreign Affairs. 2019. http://interkomitet.ru/blog/2019/10/23/rossiya-v-sovete-evropy-spravochnyj-material/(Reference date October 26, 2019). 
Statistics of the Russian Supreme Court Justice Department for the 1st half of 2019 http://www.cdep.ru/index.php?id=79\&item=5083 (Reference date October 26, 2019).

Interview of the Chairman of the Investigative Committee of the Russian Federation A. Bastrykin "Rossiyskaya Gazeta" 25.07.2017

Definition of Judicial Board on criminal cases of the Supreme Court of the Russian Federation of 27.02.2019 \# 51UD18-16

Resolution of the constitutional Court of the Russian Federation of 22.03.2018 \# 12- " in the case of checking the constitutionality of parts one and three of article 107 of the Criminal procedure code of the Russian Federation in connection with the complaint of citizen S. A. Kostromin" Date of issue 27.10.2019. http://www.consultant.ru/document/cons_doc_LAW_294013/. 